\title{
Fungicide baseline for mycelial sensitivity of Exserohilum turcicum, causal agent of northern corn leaf blight
}

\author{
Roberto Luis De Rossi ${ }^{1,2}$, Erlei Melo Reis ${ }^{2}$, Ricardo Brustolin ${ }^{2}$
}

${ }^{1}$ Universidad Católica de Córdoba, Córdoba, Argentina; ${ }^{2}$ Universidade de Passo Fundo, Passo Fundo, RS, Brasil.

Autor para correspondência: Roberto Luis De Rossi (robderossi@gmail.com)

Data de chegada: 23/09/2013. Aceito para publicação em: 16/01/2015.

$10.1590 / 0100-5405 / 1931$

\section{RESUMO}

De Rossi, R. L.; Reis, E. M.; Brustolin, R. Concentração de referência de fungicidas para a inibição miceliana de isolados de Exserohilum turcicum agente causal da hemintosporiose do milho. Summa Phytopathologica, v.41, n.1, p.25-30, 2015.

\begin{abstract}
A helmintosporiose do milho, causada por Exserohilum turcicum (Et), é umas das principais doenças do milho, podendo reduzir o rendimento e a qualidade dos grãos. O objetivo desse trabalho foi determinar a sensibilidade miceliana de dez isolados de Et, cinco da Argentina e cinco do Brasil, a seis fungicidas (carbendazim, captana, fludioxinil, metalaxil, iprodiona e tiram) utilizados para tratamentos de sementes. Na determinação da concentração inibitória $\left(\mathrm{CI}_{50}\right)$, foram utilizadas sete concentrações dos fungicidas suplementadas ao meio agarizado. $\mathrm{O}$ diâmetro do crescimento miceliano foi medido com paquímetro digital. O delineamento experimental foi inteiramente casualizado com quatro
\end{abstract}

repetições. Os dados da porcentagem de inibição do crescimento miceliano, foram submetidos à análise de regressão logarítmica e calculada a $\mathrm{CI}_{50}$. $\mathrm{O}$ fungicida iprodiona, foi o mais potente com $\mathrm{CI}_{50}<0,01 \mathrm{mg} / \mathrm{L}$, seguido pelo fludioxonil com $0,31 \mathrm{mg} / \mathrm{L}$ e tiram $1,37 \mathrm{mg} / \mathrm{L}$. Os fungicidas carbendazim, metalaxil e captana foram classificados como não fungitóxicos, $\operatorname{com} \mathrm{CI}_{50}>$ $50 \mathrm{mg} / \mathrm{L}$ para todos os isolados. O fungicida iprodiona, a pesar de ser o mais potente, não é utilizado no tratamento de sementes de milho. $\mathrm{As} \mathrm{CI}_{50 \mathrm{~s}}$ obtidas nesse trabalho podem ser utilizadas como referência para estudos futuros de monitoramento da sua sensibilidade de Et a fungicidas.

Palavras-chave adicionais: concentração inibitória de referência, fungitoxidade, helmintosporiose, Helminthosporium turcicum, Zea mays,

\section{ABSTRACT}

De Rossi, R. L.; Reis, E. M.; Brustolin, R. Fungicide baseline for mycelial sensitivity of Exserohilum turcicum, causal agent of northern corn leaf blight. Summa Phytopathologica, v.41, n.1, p.25-30, 2015.

Northern corn leaf blight, caused by Exserohilum turcicum (Et), is one of the major corn diseases which can reduce grain yield and quality. The aim of this study was to determine the mycelial sensitivity of ten $E t$ isolates, five from Argentina and five from Brazil, to six fungicides (carbendazim, captan, fludioxinil, metalaxyl, iprodione and thiram) used in seed treatment. The inhibitory concentration $\left(\mathrm{IC}_{50}\right)$ was determined by using seven concentrations of the fungicides supplemented to the agar medium. The mycelial colony diameter was measured with a digital caliper. Experimental design was completely randomized with four replicates. Data on the percent mycelial growth inhibition were analyzed by logarithmic regression and the $\mathrm{IC}_{50}$ was calculated. The fungicide iprodione was the most potent, with $\mathrm{IC}_{50}<0.01 \mathrm{mg} / \mathrm{L}$, followed by fludioxonil, $\mathrm{IC}_{50} 0.31 \mathrm{mg} / \mathrm{L}$, and thiram, $1.37 \mathrm{mg} / \mathrm{L}$. Carbendazim, metalaxyl and captan were classified as non-fungitoxic, showing $\mathrm{IC}_{50}>50 \mathrm{mg} / \mathrm{L}$ for all isolates. Although iprodione is the most potent fungicide, it is not used for corn seed treatment. The $\mathrm{IC}_{50}$ obtained in this study can be used as baseline for future monitoring studies of $E t$ sensitivity to fungicides.

Additional keywords: baseline inhibitory concentration, fungitoxicity, helmintosporiosis, Helminthosporium turcicum, Zea mays.

Northern corn leaf blight (NCLB), one of the major corn diseases, is caused by Exserohilum turcicum Leonard \& Suggs (synon. Helminthosporium turcicum Pass) [teleomorph Setosphaeria turcica (Lutterell), synon. Trichometasphaeria turcica Lutterell Leonard \& Suggs (7)]. Sporadic outbreaks most frequently occur in southern and western parts of Brazil, where the disease causes severe damage to grain yield (6). The damage can be of up to $50 \%$ (11), depending on the weather conditions, especially when infection occurs at flowering stage $(2,16)$.

In a recent study, the presence of Exserohilum turcicum $(E t)$ infecting corn and popcorn seed was quantified (3). Studies have been conducted to demonstrate and quantify the transmission from seeds to above-ground plant organs. Accordingly, we seek to manage the disease in susceptible corn hybrids by means of seed treatment with fungicides that lead to eradication and crop rotation.

A fungal sensitivity to a toxic substance is quantified by the ED (effective dose), EC (effective concentration), or IC (inhibitory concentration). The $\mathrm{IC}_{50}$ refers to the concentration of a chemical which inhibits $50 \%$ of the mycelial growth, or the germination of potentially viable spores (12).

The $\mathrm{IC}_{50}$ of different specific fungicides to $E t$, isolated from corn for both seed or foliar treatments, can be useful to disease management with the most potent chemicals.

In the available literature, there were no data on fungicide baseline to monitor $E t$ sensitivity in future studies and to use the most toxic one for corn seed treatment. 
We hypothesized that Et populations in Argentina and Brazil are still sensitive to fungicides used in seed treatment.

The aim of this study was to determine the in vitro baseline for the mycelial sensitivity of ten $E t$ isolates to the fungicides.

\section{MATERIAL AND METHODS}

The experiments were conducted at the Laboratory of Plant Pathology - Mycology, Faculty of Agronomy and Veterinary Medicine, University of Passo Fundo (UPF), Passo Fundo/RS, 2012.

Et mycelial sensitivity to the fungicide was determined on agar medium supplemented with fungicide, as proposed by Russel (15).

Isolates of Exserohilum turcicum. Et isolates used in the experiments were obtained from single spores, isolated from corn leaves with NCLB symptoms, collected in the 2011 growing season from five corn fields in the province of Córdoba, Argentina, and five from Rio Grande do Sul, Brazil. Pure cultures of each isolate were preserved in test tubes containing potato dextrose agar (Merck, $39 \mathrm{~g} / \mathrm{L}$

Table 1. Identification of Exserohilum turcicum isolated from corn

\begin{tabular}{ccc}
\hline Country & Cultivar & Code \\
\hline Argentina & AW 190 & 01-AR \\
Argentina & DK 670 & 02-AR \\
Argentina & DK 747 & 03-AR \\
Argentina & NK 910 & 04-AR \\
Argentina & P31Y05 & 05-AR \\
Brazil & AG 1145 & 01-BR \\
Brazil & AG 8011 & 02-BR \\
Brazil & AG 9010 & 03-BR \\
Brazil & DKB 350 & 04-BR \\
Brazil & H 8025 & 05-BR \\
\hline
\end{tabular}

water) kept in the refrigerator at $5^{\circ} \mathrm{C}$. The origin and identification of isolates from Argentina are: AW190MGRR2 (01-AR), DK670MG (02AR), DK747MG (03-AR), NK910TDMAX (04-AR) and P31Y05H (05-AR); and from Brazil: AG 9045 conventional (01-BR), AG 8011 Pro (02-BR), AG 9010 Pro (03-BR); DKB 350 Pro (04-BR) and AG 8025 H (05-BR) (Table 1).

Fungicides. Six fungicides were selected, of which five are routinely used in commercial corn seed treatment: captan, carbendazim, fludioxonil, metalaxyl and thiram (9), and iprodione, potent against dark mycelial fungi such as Bipolaris sorokiniana (Sacc.) Sorok, Drechslera tritici-repentis (Died,) Shoem; D. siccans (Died.) Shoem. and D. teres (Sacc.) Shoem, used in wheat and barley seed treatment (13). The following fungicides [technical name, trade name, active ingredient $(\mathrm{g} / \mathrm{L})$ and chemical group] were used in the tests: i) captan (Captan 500) phthalimide; ii) carbendazim (Derosal 500), benzimidazole, iii) iprodione (Rovral 500), dicarboximide, iv) fludioxonil (Maxim 25), phenylpyrrole, v) metalaxyl-m (Apron XL 33), acetylalaninate, vi) thiram (Rhodiauram 65.9), dimethyldithiocarbamate (1).

In vitro mycelial sensitivity of Exserohilum turcicum to fungicides. For the mycelial growth sensitivity evaluation, molten potato dextrose agar (PDA) (Merck, $39 \mathrm{~g} / \mathrm{L}$ water) medium was added of different concentrations of the fungicides, similarly to the method described by Russel (15). Seven concentrations of each fungicide were assessed: $0.00,0.01,0.10,1.00,10.00,25.00$ and $50.00 \mathrm{mg}$ of active ingredient per liter of PDA. The $0.00 \mathrm{mg} / \mathrm{L}$ concentration represented the control treatment. These concentrations were obtained by diluting fungicide stock suspensions in sterile distilled water (SDW). The final suspensions were prepared in Erlenmeyer flasks by adding the required volumes of the stock suspensions to the PDA medium.

After autoclaving, the stock suspensions were prepared in flasks containing SDW under a laminar flow hood and the fungicidal suspension was added, resulting in a final volume of $100 \mathrm{~mL}$ (stock suspension 1). From this first suspension, $1.0 \mathrm{~mL}$ was transferred to 99.0 $\mathrm{mL}$ volumetric flask to another ADE, resulting in the second dilution (stock solution 2). Afterwards, the required volumes of each suspension were added to PDA so that the desired concentrations were obtained.

Table 2. Isolates, equation, coefficient of determination $\left(\mathrm{r}^{2}\right), 50 \%$ mycelial inhibitory concentration $\left(\mathrm{IC}_{50}\right)$, and sensitivity classification of Exserohilum turcicum to captan

\begin{tabular}{|c|c|c|c|c|c|}
\hline Isolate & *Equation & $\mathbf{r}^{2}$ & $* * \mathbf{I C}_{50}$ & $\mathbf{p}$ & $* * *$ Sensitivity \\
\hline $01-\mathrm{AR}$ & $(-)$ & $(-)$ & $>50$ & n.s. & I \\
\hline 02-AR & $y=11.55 \ln (x)+32.30$ & 0.76 & 3.96 & $<0.01$ & MS \\
\hline 03-AR & $y=7.69 \ln (x)+21.32$ & 0.61 & 41.65 & $<0.01$ & LS \\
\hline 04-AR & $y=5.46 \ln (x)+13.36$ & 0.47 & $>50$ & $<0.01$ & I \\
\hline $05-\mathrm{AR}$ & $y=4.17 \ln (x)+9.62$ & 0.30 & $>50$ & $<0.01$ & I \\
\hline 01-BR & $\mathrm{y}=4.87 \ln (\mathrm{x})+11.71$ & 0.41 & $>50$ & $<0.01$ & I \\
\hline 02-BR & $\mathrm{y}=4.47 \ln (\mathrm{x})+10.44$ & 0.32 & $>50$ & $<0.01$ & I \\
\hline 03-BR & $(-)$ & $(-)$ & $>50$ & n.s. & I \\
\hline 04-BR & $(-)$ & $(-)$ & $>50$ & n.s. & I \\
\hline 05-BR & $y=8.96 \ln (x)+29.60$ & 0.67 & 10.54 & $<0.01$ & LS \\
\hline Mean & $y=6.59 \ln (x)+18.08$ & 0.61 & $>50$ & $<0.01$ & I \\
\hline
\end{tabular}

n.s. (non-significant), $* y=$ percent mycelial growth inhibition.

** Concentration $(\mathrm{mg} / \mathrm{L})$ calculated by the equation.

*** I (insensitive), MS (moderately sensitive), LS (low sensitive).

( - ) not possible to obtain numerical values. 
Table 3. Isolates, equation, coefficient of determination $\left(\mathrm{r}^{2}\right), 50 \%$ mycelial inhibitory concentration $\left(\mathrm{IC}_{50}\right)$, and sensitivity classification of Exserohilum turcicum to carbendazim

\begin{tabular}{|c|c|c|c|c|c|}
\hline Isolate & Equation* & $\mathbf{r}^{2}$ & $\mathrm{IC}_{50} * *$ & $p$ & Sensitivity*** \\
\hline 01-AR & $(-)$ & $(-)$ & $>50$ & n.s. & I \\
\hline 02-AR & $(-)$ & $(-)$ & $>50$ & n.s. & I \\
\hline 03-AR & $(-)$ & $(-)$ & $>50$ & n.s. & I \\
\hline 04-AR & $\mathrm{y}=1.08 \ln (\mathrm{x})+3.29$ & 0.79 & $>50$ & $<0.01$ & I \\
\hline 05-AR & $(-)$ & $(-)$ & $>50$ & n.s. & I \\
\hline 01-BR & $(-)$ & $(-)$ & $>50$ & n.s. & I \\
\hline 02-BR & $(-)$ & $(-)$ & $>50$ & n.s. & I \\
\hline 03-BR & $(-)$ & $(-)$ & $>50$ & n.s. & I \\
\hline 04-BR & $(-)$ & $(-)$ & $>50$ & n.s. & I \\
\hline 05-BR & $y=0.58 \ln (x)+1.75$ & 0.79 & $>50$ & $<0.01$ & I \\
\hline Mean & $\mathrm{y}=0.38 \ln (\mathrm{x})+1.35$ & 0.87 & $>50$ & 0.02 & I \\
\hline
\end{tabular}

n.s. (non-significant), *y = percent mycelial growth inhibition.

**Concentration $(\mathrm{mg} / \mathrm{L})$ calculated by the equation.

*** I (insensitive).

( - ) not possible to obtain numerical values.

Table 4. Isolates, equation, coefficient of determination $\left(\mathrm{r}^{2}\right), 50 \%$ mycelial inhibitory concentration $\left(\mathrm{IC}_{50}\right)$, and sensitivity classification of Exserohilum turcicum to metalaxyl

\begin{tabular}{|c|c|c|c|c|c|}
\hline Isolate & Equation* & $\mathbf{r}^{2}$ & $\mathrm{IC}_{50}^{* * *}$ & $\mathbf{p}$ & Sensitivity**** \\
\hline 01-AR & $y=0.74 \ln (x)+1.68$ & 0.25 & $>50$ & $<0.01$ & I \\
\hline 02-AR & $y=10.09 \ln (x)+29.65$ & 0.81 & $>50$ & $<0.01$ & I \\
\hline 03-AR & $(-)$ & $(-)$ & $>50$ & n.s. & I \\
\hline 04-AR & $(-)$ & $(-)$ & $>50$ & n.s. & I \\
\hline 05-AR & $(-)$ & $(-)$ & $>50$ & n.s. & I \\
\hline 01-BR & $(-)$ & $(-)$ & $>50$ & n.s. & I \\
\hline 02-BR & $(-)$ & $(-)$ & $>50$ & n.s. & I \\
\hline 03-BR & $(-)$ & $(-)$ & $>50$ & n.s. & I \\
\hline 04-BR & $(-)$ & $(-)$ & $>50$ & n.s. & I \\
\hline 05-BR & $(-)$ & $(-)$ & $>50$ & n.s. & I \\
\hline Mean & $y=1.46 \ln (x)+4.02$ & 0.71 & $>50$ & $<0.01$ & I \\
\hline
\end{tabular}

n.s. (non-significant), $* y=$ percent mycelial growth inhibition.

** Concentration $(\mathrm{mg} / \mathrm{L})$ calculated by the equation.

*** I (insensitive).

( - ) not possible to obtain numerical values.

Stock suspension 1 for the high concentrations (10.0, 15.0 and 50.0 $\mathrm{mg} / \mathrm{L})$ and stock 2 for low concentrations $(0.01,0.1,1.0 \mathrm{mg} / \mathrm{L})$ were used. The flasks were carefully shaken and poured into plastic Petri dishes (size $60 \times 10 \mathrm{~mm}$ ) under a laminar flow hood.

Mycelial plugs, $4 \mathrm{~mm}$ diameter, taken from 15-day-old colonies of each isolate, were transferred onto Petri dishes containing the substrate supplemented with fungicides. Discs were placed upside down on the center of the plates to allow contact with the substrate. The plates were sealed with PVC film and incubated in a growth chamber at 25 $\pm 2{ }^{\circ} \mathrm{C}$ in the dark.

Assessment. Colony diameters were measured with a digital caliper (Mitutoyo, Model 500-143B) in two perpendicular radii, when fungal growth in the control treatment reached the plate edge.

Statistics. The experiment was conducted in a completely randomized factorial design (fungicide $\mathrm{x}$ isolate) with seven treatments (concentrations) and four replicates. A Petri dish was used as experimental unit; experiments were performed twice to ensure accuracy of data, and the average of two experiments was used for statistical analysis. Et colony diameter $(\mathrm{mm})$ was converted into percent mycelial inhibition for each treatment, compared to control, and subjected to logarithmic regression analysis using the statistical program InfoStat (4) and Microsoft Excel. The concentration capable of inhibiting $50 \%$ of the mycelium growth $\left(\mathrm{IC}_{50}\right)$ for each $E t$ isolate and fungicide was calculated based on the generated equation. 
Table 5. Isolates, equation, coefficient of determination $\left(\mathrm{r}^{2}\right), 50 \%$ mycelial inhibitory concentration $\left(\mathrm{IC}_{50}\right)$, and sensitivity classification of Exserohilum turcicum to thiram

\begin{tabular}{|c|c|c|c|c|c|}
\hline Isolate & Equation* & $\mathbf{r}^{2}$ & $\mathrm{IC}_{50} * *$ & $\mathbf{p}$ & Sensitivity $* * *$ \\
\hline 01-AR & $\mathrm{y}=14.61 \ln (\mathrm{x})+45.43$ & 0.82 & 1.36 & $<0.01$ & MS \\
\hline 02-AR & $y=14.84 \ln (x)+43.90$ & 0.78 & 1.50 & $<0.01$ & MS \\
\hline 03-AR & $\mathrm{y}=14.31 \ln (\mathrm{x})+47.63$ & 0.87 & 1.18 & $<0.01$ & MS \\
\hline 04-AR & $\mathrm{y}=14.03 \ln (\mathrm{x})+47.42$ & 0.90 & 1.20 & $<0.01$ & MS \\
\hline 05-AR & $y=13.68 \ln (x)+40.70$ & 0.80 & 1.97 & $<0.01$ & MS \\
\hline 01-BR & $y=14.17 \ln (x)+48.61$ & 0.90 & 1.10 & $<0.01$ & MS \\
\hline 02-BR & $y=13.85 \ln (x)+43.80$ & 0.86 & 1.56 & $<0.01$ & MS \\
\hline 03-BR & $y=14.03 \ln (x)+47.42$ & 0.90 & 1.20 & $<0.01$ & MS \\
\hline 04-BR & $\mathrm{y}=14.84 \ln (\mathrm{x})+43.90$ & 0.78 & 1.50 & $<0.01$ & MS \\
\hline $05-\mathrm{BR}$ & $\mathrm{y}=14.40 \ln (\mathrm{x})+45.70$ & 0.83 & 1.35 & $<0.01$ & MS \\
\hline Mean & $\mathrm{y}=14.19 \ln (\mathrm{x})+45.46$ & 0.86 & 1.37 & $<0.01$ & MS \\
\hline
\end{tabular}

n.s. (non-significant), *y = percent mycelial growth inhibition.

**Concentration $(\mathrm{mg} / \mathrm{L})$ calculated by the equation.

*** MS (moderately sensitive).

Tabela 6. Isolates, equation, coefficient of determination $\left(\mathrm{r}^{2}\right), 50 \%$ mycelial inhibitory concentration $\left(\mathrm{IC}_{50}\right)$, and sensitivity classification of Exserohilum turcicum to fludioxonil

\begin{tabular}{cccccc}
\hline Isolate & $*$ Equation & $\mathbf{r}^{\mathbf{2}}$ & $* * \mathbf{I C}_{\mathbf{5 0}}$ & \multicolumn{2}{c}{$* *$ Sensitivity } \\
\hline 01-AR & $\mathrm{y}=12.46 \ln (\mathrm{x})+60.80$ & 0.90 & 0.42 & $<0.01$ & HS \\
02-AR & $\mathrm{y}=7.42 \ln (\mathrm{x})+80.65$ & 0.77 & 0.02 & $<0.01$ & HS \\
03-AR & $\mathrm{y}=10.96 \ln (\mathrm{x})+66.17$ & 0.93 & 0.23 & $<0.01$ & HS \\
04-AR & $\mathrm{y}=13.05 \ln (\mathrm{x})+59.73$ & 0.90 & 0.47 & $<0.01$ & HS \\
05-AR & $\mathrm{y}=12.11 \ln (\mathrm{x})+63.50$ & 0.92 & 0.33 & $<0.01$ & HS \\
01-BR & $\mathrm{y}=11.73 \ln (\mathrm{x})+64.67$ & 0.92 & 0.29 & $<0.01$ & HS \\
02-BR & $\mathrm{y}=13.16 \ln (\mathrm{x})+58.06$ & 0.90 & 0.54 & $<0.01$ & HS \\
03-BR & $\mathrm{y}=10.56 \ln (\mathrm{x})+67.78$ & 0.93 & 0.19 & $<0.01$ & HS \\
04-BR & $\mathrm{y}=11.67 \ln (\mathrm{x})+65.19$ & 0.88 & 0.27 & $<0.01$ & HS \\
05-BR & $\mathrm{y}=11.03 \ln (\mathrm{x})+66.50$ & 0.93 & 0.22 & $<0.01$ & HS \\
\hline Mean & $\mathrm{y}=11.48 \ln (\mathrm{x})+63.30$ & 0.92 & 0.31 & $<0.01$ & HS \\
\hline
\end{tabular}

n.s. (non-significant), $* \mathrm{y}=$ percent mycelial growth inhibition.

** Concentration $(\mathrm{mg} / \mathrm{L})$ calculated by the equation.

*** HS (highly sensitive).

\section{RESULTS AND DISCUSSION}

The reference $\mathrm{IC}_{50}$ is the mean determined for several samples of the still sensitive population or for wild strains. This concentration is specific to a given fungicide and a given fungal strain. The baseline is used to compare the power between fungicides, especially to monitor the sensitivity in order to identify whether there was reduced sensitivity over the years of fungicide use in the crop. Without the $\mathrm{IC}_{50}$ for the wildtype strain, it cannot be used in the future to quantify the reduction/ loss in sensitivity.

There are few studies on the efficacy of chemical control in this pathosystem, especially in relation to seed treatment.

The sensitivity of isolates to the tested fungicides can be classified based on the standard criteria of Edgington \& Klew (5). In the present study, it was adapted according to the following attributes: insensitive (I), when $\mathrm{IC}_{50}>50 \mathrm{mg} / \mathrm{L}$; low sensitivity (LS), when the $\mathrm{IC}_{50}$ is between 10 and $50 \mathrm{mg} / \mathrm{L}$; moderately sensitive (MS), when $\mathrm{IC}_{50}$ is between 1 and $10 \mathrm{mg} / \mathrm{L}$; and highly sensitive (HS), when $\mathrm{IC}_{50}<1 \mathrm{mg} / \mathrm{L}$.

The sensitivity of the ten isolates was classified as: insensitive (I) for fungicides captan, metalaxyl and carbendazim, moderately sensitive (MS) for thiram, and highly sensitive (HS) for fungicides iprodione and fludioxonil (Tables, 2, 3, 4, 5, 6, 7).

Most of the results are the means of two experiments, but those involving carbendazim, captan and metalaxyl were repeated three times.

The active ingredient captan was the only one that showed variation in fungitoxicity among the isolates (Table 2). On the other hand, 


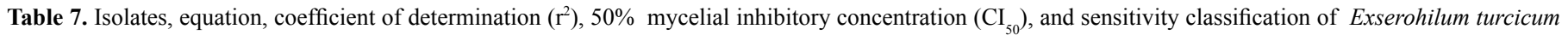
to iprodione

\begin{tabular}{|c|c|c|c|c|c|}
\hline Isolate & *Equation & $\mathbf{r}^{2}$ & $* * \mathbf{I} \mathbf{C}_{\mathbf{5 0}}$ & $\mathbf{p}$ & $* * *$ Sensitivity \\
\hline 01-AR & $\mathrm{y}=3.28 \ln (\mathrm{x})+90.38$ & 0.82 & $<0.01$ & $<0.01$ & HS \\
\hline 02-AR & $\mathrm{y}=2.12 \ln (\mathrm{x})+93.02$ & 0.95 & $<0.01$ & $<0.01$ & HS \\
\hline 03-AR & $\mathrm{y}=2.24 \ln (\mathrm{x})+93.97$ & 0.84 & $<0.01$ & $<0.01$ & HS \\
\hline 04-AR & $y=6.55 \ln (x)+81.00$ & 0.90 & $<0.01$ & 0.044 & HS \\
\hline 05-AR & $y=5.40 \ln (x)+83.88$ & 0.89 & $<0.01$ & 0.018 & HS \\
\hline 01-BR & $y=4.66 \ln (x)+86.42$ & 0.93 & $<0.01$ & $<0.01$ & HS \\
\hline 02-BR & $y=4.05 \ln (x)+87.13$ & 0.93 & $<0.01$ & $<0.01$ & HS \\
\hline 03-BR & $\mathrm{y}=2.42 \ln (\mathrm{x})+91.97$ & 0.97 & $<0.01$ & $<0.01$ & HS \\
\hline 04-BR & $y=5.72 \ln (x)+83.85$ & 0.90 & $<0.01$ & 0.050 & HS \\
\hline 05-BR & $y=2.11 \ln (x)+92.66$ & 0.94 & $<0.01$ & $<0.01$ & HS \\
\hline Mean & $y=3.82 \ln (x)+88.54$ & 0.93 & $<0.01$ & $<0.01$ & HS \\
\hline
\end{tabular}

n.s. (non-significant), ${ }^{*} \mathrm{y}=$ percent mycelial growth inhibition.

$* *$ Concentration $(\mathrm{mg} / \mathrm{L})$ calculated by the equation.

$* * *$ HS (highly sensítive).

Table 8. Fungicide concentration to inhibit 50\% $\left(\mathrm{IC}_{50}\right)$ mycelial growth of Exserohilum turcicum isolates

\begin{tabular}{|c|c|c|c|c|c|c|}
\hline \multirow{2}{*}{ Isolate } & \multicolumn{6}{|c|}{ Fungicide } \\
\hline & Carbendazim & Metalaxyl & Captan & Thiram & Fludioxonil & Iprodione \\
\hline 01-AR & $B>50 a$ & $B>50 a$ & $\mathrm{~B}>50 \mathrm{a}$ & A $1.36 \mathrm{a}$ & A $0.42 \mathrm{a}$ & $\mathrm{A}<0.01 \mathrm{a}$ \\
\hline 02-AR & $\mathrm{B}>50 \mathrm{a}$ & $B>50 a$ & A $3.96 \mathrm{~b}$ & A $1.50 \mathrm{a}$ & A $0.02 \mathrm{a}$ & $\mathrm{A}<0.01 \mathrm{a}$ \\
\hline 03-AR & $\mathrm{B}>50 \mathrm{a}$ & $B>50 a$ & B $41.65 \mathrm{a}$ & A $1.18 \mathrm{a}$ & A $0.23 \mathrm{a}$ & $\mathrm{A}<0.01 \mathrm{a}$ \\
\hline 04-AR & $B>50 a$ & $B>50 a$ & $\mathrm{~B}>50 \mathrm{a}$ & A $1.20 \mathrm{a}$ & A $0.47 \mathrm{a}$ & $\mathrm{A}<0.01 \mathrm{a}$ \\
\hline $05-\mathrm{AR}$ & $B>50 a$ & $B>50 a$ & $\mathrm{~B}>50 \mathrm{a}$ & A $1.97 \mathrm{a}$ & A $0.33 \mathrm{a}$ & $\mathrm{A}<0.01 \mathrm{a}$ \\
\hline 01-BR & $\mathrm{B}>50 \mathrm{a}$ & $B>50 a$ & $\mathrm{~B}>50 \mathrm{a}$ & A $1.11 \mathrm{a}$ & A 0.29 a & $\mathrm{A}<0.01 \mathrm{a}$ \\
\hline 02-BR & $B>50 a$ & $B>50 a$ & $\mathrm{~B}>50 \mathrm{a}$ & A $1.56 \mathrm{a}$ & A 0.54 a & $\mathrm{A}<0.01 \mathrm{a}$ \\
\hline 03-BR & $B>50 a$ & $B>50 a$ & $\mathrm{~B}>50 \mathrm{a}$ & A $1.22 \mathrm{a}$ & A 0.19 a & $\mathrm{A}<0.01 \mathrm{a}$ \\
\hline 04-BR & $B>50 a$ & $B>50 a$ & $\mathrm{~B}>50 \mathrm{a}$ & A $1.50 \mathrm{a}$ & A $0.27 \mathrm{a}$ & $\mathrm{A}<0.01 \mathrm{a}$ \\
\hline 05-BR & $C>50 a$ & $C>50 a$ & B $10.54 b$ & $\mathrm{AB} 1.35 \mathrm{a}$ & A $0.22 \mathrm{a}$ & $\mathrm{A}<0.01 \mathrm{a}$ \\
\hline Mean & $B>50$ & $\mathrm{~B}>50$ & $\mathrm{~B}>50$ & A 1.37 & A 0.31 & $\mathrm{~A}<0.01$ \\
\hline CV (\%) & \multicolumn{6}{|c|}{24.83} \\
\hline
\end{tabular}

Means followed by the same letter do not differ according to Tukey's test at 5\%.

Lowercase letters compare means in the column and the uppercase letters, in the line.

there were no variations between isolates to the active ingredients carbendazim (Table 3), metalaxyl (Table 4), thiram (Table 5), fludioxonil (Table 6), and iprodione (Table 7).

The isolate $02-\mathrm{AR}$ was most sensitive to captan, $\mathrm{IC}_{50}$ of $3.96 \mathrm{mg} / \mathrm{L}$, classified as moderately sensitive. The isolates $03-\mathrm{AR}$ and BR-05 were classified to show low sensitivity to captan, $\mathrm{IC}_{50}$ of $41.65 \mathrm{mg} / \mathrm{L}$ and $10.54 \mathrm{mg} / \mathrm{L}$, respectively. The other isolates showed $\mathrm{IC}_{50}>50 \mathrm{mg} / \mathrm{L}$ and were classified as insensitive. Regarding the isolates $01-\mathrm{RA}, 03-\mathrm{BR}$ and BR-04, it was not possible to obtain numerical values for fungitoxicity since the fungus was not inhibited, even at the maximum concentration (not statistically significant). Based on the $\mathrm{IC}_{50}$ average from the ten isolates, $E t$ was classified as insensitive to captan (Table 2).
The fungicides carbendazim (Table 3), metalaxyl (Table 4) and captan (Table 2) were classified as non-fungitoxic to $E t$, since $\mathrm{IC}_{50}$ was $>50 \mathrm{mg} / \mathrm{L}$ for all strains (carbendazim: $\mathrm{r}^{2}=0.87, p=0.02$; metalaxyl: $\mathrm{r}^{2}=0.71, p=<0.01$; captan: $\left.\mathrm{r}^{2}=0.61, p=0.01\right)$.

Regarding thiram, an average $\mathrm{IC}_{50}$ of $1.37 \mathrm{mg} / \mathrm{L}$ was determined (from $1.10 \mathrm{mg} / \mathrm{L}$ to $1.97 \mathrm{mg} / \mathrm{L} ; \mathrm{r}^{2}=0.86, p=<0.01$ ), so that $E t$ was classified as moderately sensitive to this fungicide (Table 5).

Fludioxonil showed the second best control, with an average $\mathrm{IC}_{50}$ of $0.31 \mathrm{mg} / \mathrm{L}\left(\mathrm{r}^{2}=0.92, p=<0.01\right.$; Table 6$)$. Although this active ingredient was also classified as highly fungitoxic, when compared to iprodione it was 31 times less potent $(0.31 / 0.01=31)$.

The active ingredient iprodione (Table 7) was the most potent to 
inhibit Et mycelial growth, average $\mathrm{IC}_{50}<0.01 \mathrm{mg} / \mathrm{L}\left(\mathrm{r}^{2}=0.93, p=\right.$ $<0.01)$. Thus, $E t$ isolate was classified as highly sensitive to iprodione fungicide.

The active ingredient metalaxyl belongs to the group phenylamides, effective against Peronosporales $(7,10,14)$. Metalaxyl is one of the active ingredients with specificity against representatives of the Stramenopila Kingdom (i.e. Pythium) and used in corn seed treatment to protect against seed rot in cold wet soils (14). This specificity could explain why all isolates showed $\mathrm{IC}_{50}>50 \mathrm{mg} / \mathrm{L}$, while for eight of them numerical values were not obtained as the fungus was not inhibited at any concentration (Table 4 ).

The same behavior was observed for carbendazim. Only for the isolates 04-BR and BR-05, the regression was generated (Table 3). According Reis et al. (12), not all fungi are sensitive to all fungicides (spectrum of action); some are always insensitive to certain molecules. For example, the genera Alternaria, Bipolaris, Curvularia, Drechslera, Exserohilum are insensitive to benzimidazoles, and benzimidazole is not fungitoxic to these genera.

Singh \& Kaiser (16) reported that seed treatment with carbendazim (Bavistin) or carboxin (Vitavax) effectively reduced the incidence of leaf blight caused by $E t$ in corn plants under artificial conditions, in disagreement with our study.

On the average, considering 10 isolates and six fungicides, $\mathrm{IC}_{50}$ was $>50 \mathrm{mg} / \mathrm{L}$ for carbendazim, metalaxyl and captan, 1.37 for thiram, 0.31 for fludioxonil, and $<0.01 \mathrm{mg} / \mathrm{L}$ for iprodione, the most potent one (Table 8).

The active ingredients captan, carbendazim and metalaxyl were nontoxic to Et. Although iprodione was the most potent in inhibiting Et mycelial growth, this fungicide is not used in corn seed treatment.

According to our results, the $\mathrm{IC}_{50}$ determined for different fungicides could be used as a baseline for future studies monitoring the sensitivity of $E t$ to fungicides.

\section{REFERENCES}

1. Brasil. Ministério da Agricultura, Pecuária e Abastecimento (MAPA). Coordenação-Geral de Agrotóxicos e Afins. Agrofit: Sistema de agrotóxicos e fitossanitártios. Dispoível em $:<$ http://extranet.agricultura.gov.br/ agrofit_cons/principal_agrofit_cons $>$. Acesso em de 20013.

2. Balmer, E. Doenças de milho. In. Galli, F. ed. Manual de Fitopatologia. Piracicaba: Ceres, v.20, 1980. p.371-391.

3. De Rossi, R.L.; Reis, E.M.; Brustolin, R.. Semi selective medium to detect Exserohilum turcicum in corn seeds. Summa Phytopathologica, Botucatu, v.40, n.2, p.163-167, 2014.

4. Dirienzo, J.A.; Balzarini, M.; Casanoves, F.; Gonzalez, L.; Tablada, M. \& Robledo, C.W. InfoStat, software estadístico. Cordoba. Universidad Nacional de Córdoba, 2010.

5. Edgington, L. V. \& Klew, K. L. Fungitoxic spectrum of benzimidazole compounds. Phytopathology, St. Paul, n. 61, p. 42-44. 1971.

6. Esteves, M.C.F. Reações a Exserohilum turcicum (Pass.) Leonard \& Suggs em milho (Zea mays L.) e variabilidade do patógeno. 1989. Piracicaba. Dissertação (Mestrado Fitotecnica) - Universidade de São Paulo, Escola Superior de Agricultura “Luiz de Queiróz”, Piracicaba. 1989.

7. Frederiksen, R.A. Compedium of sorghum diseases. St. Paul, American Phytopathology Society, 1991. $82 \mathrm{p}$.

8. Fuller, M.S.; Gisi, U. Miscellaneous fungicides. Comperative studies on the in vitro activity of the fungicides oxadixyl and metalaxyl. Mycologia, New York, v. 77, p. 424-32. 1985.

9. Reunião Técnica anual de milho e sorgo. Indicações técnicas para o cultivo de milho e de sorgo no rio grande do sul. Safras 2009/2010 e 2010/2011. Veranópolis, RS.2009. p.179.

10. Köller, W. Chemical approaches to managing plant pathogens. In: Rubersorn, J.R. (Ed.). Handbook of integrated pest management. New York: Dekkker, 1998. p. 1-38.

11. Raymundo, A.D.; Hooker, A.L. Measuring the relationship between northern corn leaf blight and yield losses. Plant Disease, St. Paul, v. 65, p. 325-327, 1981.

12. Reis, E. M.; Reis. A. C.; Carmona, M. A. (2010) Manual de fungicidas: guia para o controle químico de doenças de plantas. 6 . ed. Passo Fundo: Editora UPF,2010, p.226.

13. Reis, E.M.; Danelli, A.L.D.; Casa, R.T. Fungicides, seed dresser adjuvants and storage time in the control of Drechslera teres in barley seeds. Summa Phytopathologica, Botucatu, v.38, n.3, p.187-191, 2012.

14. Roberts, T.; Hutson, D. Metabolic pathways of agrochemicals. Part two, insecticides and fungicides. The Royal society of chemistry. 1999.

15. Russel, P.E. Sensitivity baselines in fungicide resistance research and management. (FRAC Monograph, 3). CB2 4AN, UK. 2004. Cambridge.

16. Singh, R.D.N. \& Kaiser, S.A. Seed treatment with Bavistin and Vitavax on the incidence of turcicum leaf blight of maize at pre-tassel stage. Indian Journal of Mycological Research, New Delhi, v.27, p. 31-35. 1989. 